Check for updates

The BMJ

Cite this as: $B M J 2021 ; 372: n 288$ http://dx.doi.org/10.1136/bmj.n288 Published: 29 January 2021

\section{Covid-19: Sore throat, fatigue, and myalgia are more common with new UK variant}

\author{
Elisabeth Mahase
}

People infected with the new variant of covid-19 discovered in the South East of England (known as B.1.1.7 or VUI 202012/01) are more likely to have a cough, sore throat, fatigue, or myalgia than those infected with other variants, the Office for National Statistics has reported.

The data, published 27 January, also show that people with the new variant are less likely to experience a loss of sense of smell or taste. These findings have prompted some doctors to call for the official covid-19 symptom list to be reviewed and potentially expanded-something that has not happened since May 2020. The UK government currently advises that people get tested for covid-19 if they have a high temperature, a new, continuous cough, or a loss or change to their sense of smell or taste.

The B.1.1.7 variant is thought to be much more infectious ${ }^{2}$ and possibly more deadly-although this is still being investigated. ${ }^{3}$ The Office for National Statistics compared B.1.1.7 to other variants by looking at which genes were positive on the PCR test. The test checks for three genes found in SARS-CoV-2: the N protein, S protein, and ORF1ab. B.1.1.7 has genetic changes in the $S$ gene, which means that people with this variant do not test positive for the $S$ gene; most other common variants test positive for all three genes (a triple positive).

The report, which covered cases in England from 15 November 2020 to 16 January 2021, said, "Loss of taste and loss of smell were significantly less common in new variant compatible positives than triple positives, whereas other symptoms were more common in new variant compatible positives, with the largest differences for cough, sore throat, fatigue, myalgia, and fever. There is no evidence of difference in gastrointestinal symptoms, shortness of breath, or headaches.” The report also found that the percentage of people in patient facing jobs testing positive for covid-19 has increased.

Richard Tedder, senior research investigator in medical virology at Imperial College London, said that the new data on symptoms could explain why B.1.1.7 is more transmissible. "The fact that it has been reported that the second wave viruses, usually called variants, are more likely to cause symptoms of upper respiratory tract infection, i.e. coughs and colds, may indicate that a trivial difference in the way the virus may cause disease symptoms could cause more easy transmission between people. For example, if there is an increased amount of coughing and perhaps sneezing associated with a particular variant virus, these two activities can markedly increase the amount of virus which is shed into the environment, thereby making it 'more infectious,"” he said.

\section{Updating the symptom list}

In a letter published in The BMJ,4 London GP Alex Sohal said people are "mostly unaware of the significance of mild symptoms" that could be covid-19 and called for the UK to change its case definition and testing criteria to include such symptoms.

"Tell the public, especially those who have to go out to work and their employers, that even those with mild symptoms (not only a cough, high temperature, and a loss of smell or taste) should not go out, prioritising the first five days of self-isolation when they are most likely to be infectious," she wrote. “Test more of those with symptoms, identify more infectious cases and reduce spread ...This will help to get-and keep-us out of this indefinite lockdown, as covid-19 becomes increasingly endemic globally. Ignoring this will be at our peril."

When asked about this, a Department of Health and Social Care spokesperson told The BMJ, “An expert and independent scientific group keeps the list of symptoms of covid-19 under constant review as our understanding of the virus continues to evolve.” They acknowledged that covid-19 has a much longer list of symptoms than the ones on the official list for testing but said that the symptoms included on that list capture patients most likely to have covid-19. 1 Office for National Statistics. (Covid-19) infection survey: characteristics of
people testing positive for covid-19 in England. 27 Jan 2021.
https://www. ons.gov.uk/peoplepopulationandcommunity/healthandsocial-
care/conditionsanddiseases/articles/coronaviruscovid19infectionsinthecom-
munityinengland/characteristicsofpeopletestingpositiveforcovid19ineng-
land27january2021
Mahase E. Covid-19: What have we learnt about the new variant in the
UK?BM/2020;371:m4944. https://www.bmj.com/content/371/bmj.m4944.
doi: 10.1136/bmj.m4944 pmid: 33361120
lacobucci G. Covid-19: New UK variant may be linked to increased death
rate, early data indicate. BMJ2021;372:n230. https://www.bmj.com/con-
tent/372/bmj.n230. doi: 10.1136/bmj.n230 pmid: 33500262
Sohal A. Open letter to Chris Whitty and Susan Hopkins: change covid-19
case definition in line with WHO to save lives. BMJ2021;372:n283.
doi: 10.1136/bmj.n283
This article is made freely available for use in accordance with BMJ's website
terms and conditions for the duration of the covid-19 pandemic or until otherwise
determined by BMJ. You may use, download and print the article for any lawful,
non-commercial purpose (including text and data mining) provided that all
copyright notices and trade marks are retained. 